\title{
HISTORY, POWER, AND ELECTRICITY: AMERICAN POPULAR MAGAZINE ACCOUNTS OF ELECTROCONVULSIVE THERAPY, 1940-2005
}

\author{
LAURA HIRSHBEIN* AND SHARMALIE SARVANANDA
}

\begin{abstract}
Electroconvulsive therapy (ECT) is a psychiatric treatment that has been in use in the United States since the 1940s. During the whole of its existence, it has been extensively discussed and debated within American popular magazines. While initial reports of the treatment highlighted its benefits to patients, accounts by the 1970s and 1980s were increasingly polarized. This article analyzes the popular accounts over time, particularly the ways in which the debates over ECT have revolved around different interpretations of ECT's history and its power dynamics. (C) 2008 Wiley Periodicals, Inc.
\end{abstract}

On June 25, 2005, NBC aired a Today Show interview of actor Tom Cruise during which Cruise took to task fellow actor Brooke Shields about her decision to take antidepressant medication. His remarks centered not on medication, though, but rather on the psychiatric enterprise as a whole, including electroconvulsive therapy:

I've never agreed with psychiatry, ever. Before I was a Scientologist I never agreed with psychiatry. And when I started studying the history of psychiatry, I understood more and more why I didn't believe in psychology. . . . Here we are today, where I talk out against drugs and psychiatric abuses of electric shocking people, okay, against their will, of drugging children with them not knowing the effects of these drugs. . . . You don't know the history of psychiatry. I do. (Lauer, 2005)

Cruise's avowed stance as a member of the Church of Scientology, a group that has been aggressively opposed to psychiatry in the last few decades, certainly explains the vehemence with which he attacked psychiatry. Yet he was not content to merely attack current psychiatric practice or even just medications. Instead, he invoked the evidence of history to demonstrate the problems with psychiatry, including electroconvulsive therapy. ${ }^{1}$

In 1940, the first descriptions of new treatments for mental illness appeared in the popular press in the United States: convulsive therapies or shock treatments. Magazine accounts of the time enthusiastically reported the benefits of shock for a hopeless patient population.

\footnotetext{
* I would like to thank the two anonymous reviewers who helped enormously as I worked on revisions for this paper. I would also like to thank the psychiatry residents at the University of Michigan who have engaged with me in thoughtful, provocative discussions about power and ECT.

1. Scientology has aggressively used the history of psychiatry as a weapon to attack the specialty. The public relations group connected with Scientology, the Citizens Commission on Human Rights (CCHR), has worked hard to drive ECT machine manufacturers out of business and has actively contributed in the laws limiting ECT in many states. The CCHR has recently opened a museum, "Psychiatry: The Museum of Death," that prominently features ECT.
}

Laura HirshbeIn, MD, PhD, is Assistant Professor of Psychiatry at the University of Michigan. Dr. Hirshbein completed her MD and residency training in psychiatry at the University of Michigan, and received her PhD in the history of medicine from the Johns Hopkins University. She is completing a book on the history of depression in the twentieth century, American Melancholy: A History of Depression in the United States, 1900-1990.E-mail: lauradh@med.umich.edu

Sharmalie SaRvanANDA, MD, completed her psychiatry residency training at the University of Michigan and is currently in private practice in Lapeer, Michigan. 
By the 1970s, however, shock treatment appeared much more problematic. In 1972, Senator Thomas Eagleton was forced to withdraw his Democratic vice-presidential candidacy after he revealed that he had received electroconvulsive therapy (ECT) the decade before his nomination. As popular magazine writers attempted to make sense of Eagleton's story, they particularly addressed the history of ECT: where did this therapy come from and why was it being used? A shock no longer appeared progressive, but rather suggested a potentially troubling treatment that harkened back to a dark past of psychiatric coercion. More recently, public discussions around ECT have become more and more polarized, and the history of the treatment plays a central role in these discussions. Advocates of ECT insist that present-day ECT is much better than in the past, while opponents use the concept of shock therapy in order to berate psychiatry for continuing to assert control over patients with barbaric treatments.

The different narratives about ECT and its history are part of a broader ongoing public discourse about the power of psychiatry to define normality. It is no accident that the turning point in the popular press accounts of ECT was in the 1970s - the time when many different groups within America were struggling against hegemonic psychiatric definitions of normal sexuality and gender relationships (Bayer, 1987; Tomes, 1994). Indeed, the most potent image of ECT in popular culture remains that from the 1975 film One Flew Over the Cuckoo's Nest. While the main character's experience with ECT comprises less than five minutes of screen time, ECT is very much connected with the other strategies of control that the psychiatry team exerts over the main character in the film. In retrospect, ECT opponents still find the Cuckoo's Nest image compelling because it effectively captures the power dynamics they still see as problematic in patients' encounters with psychiatry. ECT advocates respond to the Cuckoo's Nest image, in contrast, by explaining that this representation reflects past abuses, not current scientific use.

As the endurance of Cuckoo's Nest in the popular imagination indicates, the public has been and remains intensely interested in the concept of ECT. In this article, we examine popular magazine accounts of ECT and shock therapies from the 1950s through 2005 (as indexed in the Reader's Guide) in order to understand change over time in the public encounter with ECT and its changing power dynamics (Reader's Guide to Periodical Literature). Within popular representations of ECT, its history has become a way for both advocates and opponents to express their views about ECT and psychiatric power. As with other accounts of social or cultural events, including scientific or medical discoveries (Abir-Am, 1999; Bodnar, 1992; Kammen, 1991; Micale \& Porter, 1994; Novick, 1999; Silber, 1993), the histories of ECT have changed over time in response to changing social and cultural circumstances, as well as changes in the broader implications of psychiatric treatment. The history of ECT has become a metaphor for both advocates and opponents to explain their vision of psychiatric power and its promise for or threat to society.

\section{Popular Magazines And Shock Treatments, 1940-1970}

In the first half of the twentieth century, psychiatrists increasingly used new treatments on patients' bodies in order to cure, or at least ameliorate, their mental illnesses (Braslow, 1997; Scull, 2005). Convulsive therapy was originally conceived as occurring through three different mechanisms: insulin coma, metrazol shock, and electric shock (Berrios, 1997; Kneeland \& Warren, 2002; Lebensoh, 1999; Shorter, 1997; Weiner \& Coffey, 1991). These treatments were particularly used for seriously ill patients within the center of psychiatric practice of the time, the mental hospital (Grob, 1983; Lunbeck, 1994). Mentally ill patients were typically divided into groups based on their likelihood of recovery: manic-depressive patients appeared to 
recover their ability to function, while schizophrenic (or dementia praecox) patients tended to decline over time (Hoenig, 1995; Jackson, 1986; Kraepelin, 1907; Turner, 1995). All three of the convulsive therapies were originally hailed as treatments for schizophrenia, but the association of particular diagnoses with specific convulsive therapies gradually disappeared (Kalinowsky \& Worthing, 1943; Malzberg, 1943; Rennie \& Fowler, 1943).

The rationale for all forms of convulsive therapy was that the convulsion disrupted problems in the patient's thinking and restored some semblance of normality. This rationale seemed to be supported by practitioners' experiences - patients did seem to become calmer after treatments. Insulin coma treatment (which sometimes resulted in convulsions), made possible because of the exciting isolation of insulin in the 1920s (Bliss, 1984), was the first of the three convulsive therapies to be introduced in the United States in the 1930s (Appel, Farr, \& Marshall, 1928; Rinkel \& Himwich, 1959). Metrazol, a drug that was originally used for patients with heart difficulties, was used to induce convulsions that appeared to reduce or eliminate patients' agitation and psychoses (Bennett, 1939; McCrae, 2006; Menninger, 1940; Wilson, 1939). Although metrazol was robust in its ability to produce a convulsion, it was also universally disliked by patients (Kennedy, 1940; Nussbaum, 1943; E. Ziskind, SomerfeldZiskind, \& Ziskind, 1942). Electroconvulsive therapy (ECT) was developed in the late 1930s by two Italian psychiatrists who discovered how to induce convulsions with electricity. Although not all psychiatrists believed that ECT was superior to insulin, it was easier to administer and better tolerated than metrazol (Bianchi \& Chiarello, 1944; Sulzbach, Tillotson, Guillemin, \& Sutherland, 1943). ECT was modified in the late 1950s by the introduction of anesthesia (both sedation and muscle relaxation), a change in the procedure that most psychiatrists hailed as a significant improvement for patient comfort and safety (English \& Finch, 1964). Between 1940 and the late 1950s, shock treatments appeared in popular magazine accounts of seriously ill patients and their providers. Although magazine writers did make distinctions within articles among insulin, metrazol, and electric shock, the treatments were often discussed together, generally reflecting clinical practice in which they were used together (Messinger, 1941; Read, 1940).

When shock therapies were originally introduced to American popular audiences through magazines, the treatments exemplified the growing power of medical practitioners over disease. For the most part, magazine accounts of shock treatments in the 1940s and 1950s enthusiastically described the possibilities of improving very ill patients. One Science News Letter article explained that these treatments "restore to sanity the 'living dead' affected by the dementia praecox form of mental illness." In this context, the subsequent risk for vertebral fractures caused by "violent convulsive shocks" appeared entirely reasonable ("Many Spinal Fractures in Shock Treatments," 1940). One Hygiea writer emphasized that these treatments were producing success in "supposedly incurable mental disorders" (Read, 1940, p. 627). Treatment for these previously incurable diseases was not a minor accomplishment: "Coming at a time when war is subjecting the population of the whole world to those intolerable mental strains that precipitate mental disease, this new use of electricity for mental health instead of for death is being enthusiastically welcomed by the medical profession" (Van de Water, 1940, p. 42) $)^{2}$ (Messinger, 1941). Although some writers warned against becoming too enthusiastic about treatments, the recovery rates for patients undergoing convulsive therapies appeared to be much better than the usual recovery rates ("Many Mentally Ill Now Getting Shock Treatment," 1942).

2. At the time that the electric chair was introduced in the U.S. in the $1880 \mathrm{~s}$, it was hailed as a modern signal of advancing civilization. See Martschukat (2002). For more on the history of the electric chair, see Essig (2003), Moran (2002) 
While shock treatments came to prominence in America at the same time that psychoanalysis was gaining wider acceptance (Hale, 1995), there was no necessary conflict between the two types of treatments for either psychiatrists or the public (Levy \& Grinker, 1943; Menninger, 1940; Rennie \& Fowler, 1943; Rosen, Secunda, \& Finley, 1943; Sadowsky, 2006). ${ }^{3}$ Popular accounts of shock treatments used explanations and metaphors for the procedures that drew on both somatic and psychoanalytic models. As one account of ECT in 1941 explained, the shock was intended to "jolt a mental patient out of his dream world and back into sanity" ("Electric Shock Treatment Causes Partial Memory Loss," 1941, p. 182). While some writers explained this effect in terms of applied electricity to the brain (Galton, 1958; "Meeting On Minds," 1949), others used psychological terms ("Insulin Sub-Shock Treatment for Mental Illness," 1949). As a physician outlined in 1945, "the patient's subconscious mind regards the shock as a threat to his very existence. This thought so jars him that his mental conflicts take on secondary importance. The instinct of self preservation is profoundly affected and suicidal impulses quickly disappear. The patient - if he is to recover-develops a willingness to face reality" (Feldt, 1945, p. 21). A 1948 Newsweek report of shock used to treat a young woman with a very bad stutter explained that the treatment worked by releasing the "patient's inner tension" and allowed her to participate in psychotherapy ("Shock for Stammerers," 1948).

Throughout this initial period when convulsive therapies were introduced, popular commentators framed the therapies in terms of the battle of the psychiatrists against the disease ("Meeting On Minds," 1949; "More or Less Shock?," 1955; "Photoshock Treats Psychosis," 1952; L. Ziskind, 1948). Although the treatments could have negative side effects, commentators generally explained them as unavoidable consequences of the larger fight ("Electric Shock Treatment Causes Partial Memory Loss," 1941). This interpretation of ECT as one method of conquering mental illness also appeared in other popular media of the time. In the 1948 film, The Snake Pit, for example, the heroine receives a large number of therapiesfrom electric shock to hydrotherapy to narcosynthesis to psychoanalytic psychotherapy. While the heroine is clearly under the power of her psychiatrist, he is presented as a benevolent figure who uses treatments in order to "make contact" with his patient. In this context, although ECT is frightening, it is one of many tools he employs to try to help his patient. Although the patient ultimately improves with psychoanalysis (at least in the film), the psychiatrist is able to make significant inroads with her because of her other types of therapies (Fishbein, 1979; McDonald \& Walter, 2001).

Many of the early stories of the convulsive therapies placed them within a narrative of recent medical discoveries. Writers contrasted the past, which they characterized as a time without any psychiatric interventions, with the present, with its dramatic new discoveries of effective treatments. As physician Robert Feldt explained in 1945, "insanity is no longer regarded as a hopeless, hideous disease. A revolutionary new treatment is restoring sanity to thousands of patients by shocking them with drugs or electricity" (Feldt, 1945, p. 21). Feldt went on to characterize the discoveries of each of the kinds of shock treatment, emphasizing the role of scientific experiment and chance that stimulated further work. Feldt even mentioned that a psychiatrist tested electric shock therapy on himself and determined that it was safe, a true marker of both the treatment's safety and his credibility as a scientist (Lederer, 1995).

Indeed, by the $1950 \mathrm{~s}$, electric shock was so well established as a modern effective treatment that journalists who described new medical applications of shock cited psychiatry's use

3. At the University of Michigan, for example, psychiatrist Dr. Moses Frohlich was in charge of insulin, metrazol, and electric shock treatments in the 1940s, at the same time that he was undergoing his training analysis with the Detroit Psychoanalytic Society. Moses Frohlich Papers, Bentley Historical Library, University of Michigan, Ann Arbor, MI. 
of it as a model (Bukstein, 1963; "Electric Shock Stops Heart Twitching," 1957; "Electric Shock Used to Halt Heart Twitching," 1957). In 1952, physicians first used electricity on a patient in order to induce cardiac defibrillation. Articles in both Time and Newsweek explained that a cardiologist had developed a machine for shocking the heart, based on the principles of shocking patients developed in ECT. The first patient reported to have experienced cardiac defibrillation was a nurse who was helped by the direct transfer of technology: "Electric shock, which has brought back to sanity hundreds of bewildered psychotics, has saved the life of a pretty Chicago nurse whose heart had stopped beating" ("The Shocked Heart," 1952). The patient reported that she was so indebted to psychiatry after this experience that she was seriously considering going into psychiatric nursing ("Shocked to Life," 1952). ${ }^{4}$

But though convulsive therapies could act as powerful tools for practitioners ("Mental Disease Preventive," 1945), at least one commentator in the early 1950s identified problems that could result from the dynamic between practitioner and ECT patient. In 1953, journalist Lucy Freeman explained that the widespread use of convulsive therapies acted as a quick fix for patients and complained that this approach interfered with psychiatrists' abilities to truly understand their patients: "Some psychiatrists - particularly neuropsychiatrists - think people become severely troubled because something is chemically or glandularly wrong with them. They look for a magic formula that will catapult the unhappy into sudden happiness. They search for a chemical compound, a form of brain surgery, or a physical process to solve the mystery of emotional illness" (26). Freeman argued that psychiatrists needed to talk with their patients and get to know them rather than assume that a psychiatric treatment administered from a distance could solve complex human problems (Freeman, 1953). While some practitioners were very happy to embrace the idea of a somatic intervention from a distance (Laqueur, 1959; "New Shock Treatment," 1958), Freeman's concerns about the dynamics of power between patients and practitioners were expanded and amplified in the 1970s.

In the 1960s, possibly because of the rise of public awareness of psychoanalysis and new medications for mental illness (Healy, 2002), ECT seldom appeared in popular magazines. In one of the few mentions of ECT in this decade, shock appeared less progressive or precise than medications: "Drugs, as every bathroom medicine chest will testify, are more acceptable than electric current" (Schreiber \& Herman, 1965, p. 30). As we discuss below, ECT came back to popular attention in the 1970s and 1980s in a series of dramatic stories about patients, effective treatment, and side effects. In these accounts, the power issues within shock treatment began to appear to be more problematic. These power issues were often expressed from the perspective of history: was ECT a desperate measure from a bygone era, or a modern new treatment of the future?

\section{EAGLETON AND AFTERMATH}

In the summer of 1972, Senator Thomas Eagleton was selected by Democratic Presidential candidate George McGovern as his vice-presidential running mate for the upcoming election ("McGovern Begins," 1972). Only days after his nomination, however, Senator Eagleton revealed that he had been treated for "nervous troubles" in the 1960s, had been institutionalized, and had received ECT. While newspaper articles of the time seemed to indicate that the American people were not as troubled by Eagleton's history of mental difficulties as his fellow politicians ("Evaluating Eagleton," 1972), McGovern evidently thought that Eagleton would

4. The concept of shock used elsewhere in the body continued to have a positive resonance, even when ECT itself was more widely criticized. See for example, SerVaas (1981); "Shocking Alternative to Open Heart Surgery." 
be a liability and asked him to step down as candidate less than a week after his revelation ("McGovern Calls Eagleton Affair 'Saddest Part'," 1972). ${ }^{5}$ Eagleton's personal history of having received ECT generated a renewed public interest in the treatment but also represented a turning point in popular accounts of ECT. With this very high profile patient, accounts of ECT became more concerned with the power transaction that occurred with the treatment, and commentators increasingly raised questions about psychiatrists' right to wield this kind of power (Talkington, 1972). ECT coverage in popular magazines began to focus more on the effects of ECT on the patients and also became a metaphor to explore the increasingly problematic power dynamics between psychiatry and society.

In August of 1972, not long after Eagleton made his disclosure about having had ECT, both Time and Newsweek carried informative articles on ECT and Eagleton for their readers. Yet what they presented was quite different - the Time coverage was generally negative (even inflammatory), while the Newsweek coverage was more balanced and sympathetic toward Eagleton. While this is fairly easily explained by the different politics of the two news magazines, what is striking about the differences between the two portrayals of ECT is the role of history in telling the story of the treatment. The Newsweek article emphasized the ways in which modern ECT was a significant improvement over the past practice, while Time portrayed ECT as a relic from the past.

The Newsweek article explained that ECT was a poorly understood but nevertheless effective treatment that originated as an alternative to insulin convulsive therapy. The author conceded that ECT used to be "medieval" in its appearance and that this was what gave it a bad name, but modern treatments were not at all dangerous and were quite mundane: "Sponge rubber electrodes are placed like headphones above and slightly in front of each ear. The physician throws a switch on a control box that sends the shock in to the patient's brain for no more than one second. Two or three minutes later, the patient wakes up relaxed and slightly euphoric and is able to get up and walk away." Not only was the simile of headphones used to explain the electrodes, but also the photograph that accompanied the story was of a respectable, bearded white psychiatrist holding onto the equipment over a very quiet, docile, older white woman ("Depression and Electroshock," 1972). In the Newsweek account, ECT was misunderstood because of its history, but was in fact a modern, easy procedure.

The Time article constructed the history of ECT in a somewhat different way. First, the photograph that accompanied the article illustrated several African American orderlies holding down a white, male patient who was visibly convulsing. The caption beneath the photograph indicated that it was taken in 1949, but there was no explanation for why a picture from two decades before was used in the article. Further, it is easy to imagine that, at the time that this photo was published, the specter of strong, black men holding down a struggling white man could have been quite inflammatory (Ogbar, 2004; Schulman, 2001). The power struggle conveyed in this image suggested that ECT was a violent means by which psychiatrists assumed control over their patients, and the representation of that power by African American men further problematized the treatment. When the patient in question was running for office in which he would be literally a heartbeat away from the Presidency, the specter of ECT as a means for producing complete subjugation could easily mobilize the existing fears of the magazine's readership.

Not only was the image in the Time article more dramatic, the language of the treatment was not nearly as reassuring as the Newsweek account. According to the Time writer,

5. On the media coverage of the Eagleton story, see Altheide (1977), Bormann (1973), Ostlund (1973/74). On the contrast between Eagleton's experience in exposing his history of mental illness and the experience of a more recent candidate, see Strout (1995). 
"As practiced today, shock treatments are administered through electrodes attached to the patient's temples. A device the size of a file-card box is used to send an alternating current of about 400 milliamperes through the brain at roughly 100 volts for seven seconds (electric chairs employ a seven-ampere current at 50,000 volts)" ("Most Common Mental Disorder," 1972). While the dose of electricity in relation to that used in the electric chair was clearly less in ECT, the mention of the electric chair in the same sentence as ECT might have been quite alarming to readers. The author also explained that it was difficult to know how to evaluate the extent of Eagleton's illness because at the time the article was written, ECT was generally only used for the most severe cases. However, Eagleton's treatment occurred at a time (in the mid-1960s) when ECT was much more commonly used. The article implied that ECT was a procedure of the past and raised the question of whether Eagleton would have received it if treated in the present.

The public controversy around Eagleton's disclosure about his psychiatric treatment occurred at a time when a growing number of scholarly and popular writers were beginning to express significant dissatisfaction with American psychiatry. These commentators, who were part of a broad movement of social protest in the United States, particularly targeted psychiatry's power over patients (Dain, 1989; Vatz \& Weinberg, 1994). Historians and cultural critics focused on psychiatry's history of social control over patients in areas such as institutionalization (Foucault, 1967; Rothman, 1990; Tomes, 1994). In addition, as psychiatrist Max Fink pointed out in the early 1990s, anti-psychiatry activists very early targeted ECT as a problematic aspect of psychiatrist-patient relationships (Fink, 1991). Popular discussions of ECT by this time period began to reflect the broader context of criticism of psychiatry in general and of ECT in particular. In these critical pieces, ECT's history recalled a past (that may or may not have existed) in which psychiatrists actively sought out control over all aspects of patients' lives and indeed anyone else who crossed their paths. ${ }^{6}$

In 1974, the first of what would become a series of highly negative articles appeared that characterized ECT as a harmful relic from a bygone era during which psychiatrists did what they wanted with patients. New Yorker writer Berton Roueche published an extensive article about a woman who had apparently gone to a mental hospital for a rest and to avoid stress. As the article unfolded, it was revealed that the woman had lost all memory of what was happening to her at the time, or even what happened in the past. Through her inquiries, she discovered that she had been given ECT in the hospital (with questionable consent proceedings). In an interview with Roueche, she claimed that ECT had entirely erased her memory and eliminated her ability to perform at her job, even years after her treatment (Roueche, 1974). While the woman's true identity in the New Yorker article was disguised, later popular press articles revealed that she was Marilyn Rice, a once-successful federal employee. In later years, Rice organized a movement of former ECT patients that aimed to have the procedure entirely banned ("ECT: It Works, But at What Cost?," 1978).

Roueche's 1974 account of Rice's treatment not only illustrated the dangers of ECT's side effects, but also Roueche's history of the treatment itself suggested that it should be treated with great suspicion. Roueche traced the history of ECT from the eighteenth-century German neurologist Johann Reil who attempted to frighten - or shock-patients into sanity. Roueche also claimed that eighteenth-century American physician Benjamin Rush employed a kind of shock treatment. In Roueche's history, insulin treatment was really just a precursor

6. This constructed past crops up periodically in popular culture to illustrate villains. For example, Disney animators used the image of an asylum doctor (psychiatrist) who is only too happy to allow himself to be bribed to help control Belle and her father in Beauty and the Beast (1991). 
to electric shock treatment, both of which were based on a superstitious two-century old treatment method. While the mechanism for inducing convulsions had changed over time, the rationale for doing so was quite old and not particularly scientific.

Roueche's article marked the beginning of what would become a series of narratives about ECT that emphasized its history, with the implication that there were many problems with using old, even barbaric, treatments on patients. Indeed, in these narratives, the history of ECT was an active part of the argument against psychiatric treatment. Historical narratives of ECT were actually used by many activists to protest the use of psychiatric treatments on local and state levels. ECT opponents worked closely with anti-psychiatry activists who insisted that psychiatry was not scientific, that mental illness did not exist, and that psychiatrists were merely engaging in social control. In 1975, ECT opponents were able to get a statute proposed in California that would have required a review committee to oversee all decisions for ECT and psychosurgery to make sure that the patient had consented (Ellis, 1975). Even though psychosurgery was seldom performed by this time period (Pressman, 1998; Valenstein, 1986), ECT and psychosurgery were lumped together as treatments that had been performed against a patient's will in the past. Mental health advocates in California and elsewhere insisted that patients' rights with regard to ECT included the right to not be forced to undergo treatment.

The discussion around the 1975 proposed statute in California (which was eventually ruled unconstitutional) elided ECT with involuntary treatment of patients in a long (constructed) tradition of psychiatric dominance of patients through invasive practices. Indeed, one of the major activists in the law, Dr. John Friedberg, insisted that the ongoing use of ECT represented a conspiracy on behalf of psychiatrists who covered up their long-standing knowledge that ECT caused brain damage (Clark \& Lubenow, 1975). As Friedberg explained, ECT was in the tradition of "beating up those labeled insane with methods ranging from torture to lobotomy to psychosurgery" (20). He traced the evolution of ECT from Meduna (convulsive therapy) to Sakel (insulin coma) to Moniz (lobotomy) to Cerletti (electric shock) to the Germans who killed their mental patients during World War II. Indeed, he several times invoked the language of concentration camp torture in order to make his point about the dangers of the treatment (Friedberg, 1975).

But while Friedberg linked ECT's history to Nazi atrocities, ECT advocates used an evolution narrative for their history of ECT to illustrate the upward progress of modern science. They insisted that the power of ECT lay in its ability to help patients and its links to the growing power of scientific discovery in medicine. In 1977, David Avery (at that time a fellow in psychopharmacology), observed that the use of a treatment for mental illness directed toward the brain represented a major step forward in science. He suggested that the opponents of ECT had old-fashioned notions about mental illness: "The ECT controversy reflects a tendency to see a natural antagonism between science and humanism. Many critics reject the treatment because they wish to see the mind as separate from the brain-free from the biological whims that affect every other organ of the body. Yet, much can be learned from both the recent biological data and the insights of humanism" (Avery, 1977). Avery emphasized the modern views of ECT and its uses in patients and suggested that the opponents of ECT were acting under a misguided misinterpretation of the treatment. For Avery and other advocates, the power of ECT was its position within modern medical advances.

Through the late 1970s and 1980s, advocates and opponents rehashed significant events in ECT's history, particularly its origin in the work of Italian psychiatrists Cerletti and Bini in the late 1930s (Passione, 2004). According to many popular press writers, Cerletti visited a pig slaughterhouse in the 1930s and witnessed how electricity was used there. But popular 
writers used dramatically different interpretations of this story in order to make arguments about the value or horror of ECT. Journalist Maggie Scarf, who published a very sympathetic account of ECT in the New York Times Magazine in 1979, described ECT's originator Cerletti as a caring physician whose slaughterhouse investigation represented his attempt to test the effect of electrical current without endangering human life (Scarf, 1979). But while Scarf interpreted Cerletti as humane, ECT opponent John Friedberg alleged that Cerletti's visit to the pig slaughterhouse gave him the inspiration to treat humans as pigs by shocking them. In addition, Friedberg reported that Cerletti had experimented on patients without their consent, going so far as to inject a suspension of pig cells into a human being (Friedberg, 1975; Hapgood, 1980). Cerletti's relationship with the pigs was presented to illustrate the authors' assumptions about the power relationships in ECT. For Scarf, animal observation could lead to improved science and better treatments, while Friedberg placed Cerletti in a long tradition of psychiatrists who actively designed different means by which to gain control over patients.

Although differing opinions about the past and present of ECT continued to characterize popular magazine accounts, all authors could agree that ECT generated strong opinions. A Science News article in 1980 explained matter-of-factly that ECT had been controversial over the whole of its 40-year history in the United States ("Depression: Safer Shock Therapy," 1980). Most interestingly, though, by the 1980s psychiatrists began to concede that there had been abuses of ECT in the past - although they hastened to add that ECT was much better in the present (Rogers, 1982). Melvin Sabshin, at that time the medical director of the American Psychiatric Association, argued that former patients who protested the treatment were basing their ideas on treatments that had experienced more than 20 years before. Opponents of the treatment claimed that the changes in ECT were immaterial, while advocates insisted that ECT had been significantly improved (Clark, Schmidt, \& Hager, 1982; W. Herbert, 1982; W. Herbert, 1983).

In a little more than a decade from the disclosure that Thomas Eagleton had received ECT, public discussions of the treatment became a battleground in which opponents and advocates expressed their beliefs about aggressive psychiatric treatment and about psychiatry's traditional power over patients. Opponents insisted that ECT fit within a long trajectory of psychiatrists taking violent control over their patients. These narratives continued in subsequent decades as opponents laid out more and more lurid stories about victims of ECT. By the late 1980s and 1990s, though, ECT advocates shifted their focus in defending the treatment. Instead of just stressing the ways in which ECT had improved, they attempted to illustrate that the power dynamics in the treatment had changed by taking their explanations directly to popular magazines and by invoking the positive experiences of patients themselves.

\section{Polarized Accounts AND New Voices}

Thomas Eagleton was by no means the only major public figure to have popular press coverage about his treatment with ECT. Several other major celebrities also became the subject of intense public scrutiny after their treatments, some many years later. Although Ken Kesey's book One Flew Over the Cuckoo's Nest was published in 1962 (Kesey, 1962), its representation of ECT did not generate discussion in the popular press. Instead, it remained for the 1975 film of Cuckoo's Nest to dramatically illustrate ECT as a form of control (McDonald \& Walter, 2001). Although critics at the time, and later, protested that the film was not accurate in its portrayal of ECT (by the time of the film's release, ECT was usually given with anesthesia, not without it as the film depicted), the film still presented viewers with a powerful impression of ECT (Gabbard \& Gabbard, 1999). The Cuckoo's Nest image of ECT 
as a method of sadistic psychiatric control over patients permeated popular discussions of ECT, and Jack Nicholson's character as a victim of ECT appeared in popular accounts of the treatment. A 1979 Newsweek article that covered a psychiatric conference in Britain - as well as its herds of ECT protesters outside-commented that advocates of the treatment had to contend against the film image: "Proponents of ECT also point out that modern techniques are far removed from the horror of Cuckoo's Nest" ("Comeback for Shock Therapy?," 1979). Though psychiatrists insisted that ECT had changed, the film had given ECT a bad reputation that was difficult to shake. Duke psychiatrist Richard Weiner was quoted in 1984 as saying that the film representation was a problem because it scared off patients who really needed the treatment (Chinnici, 1984).

While ECT sympathizers emphasized the need to overcome the vivid (and negative) image of Jack Nicholson receiving ECT as part of a system of control, ECT opponents mobilized the image of another famous ECT recipient, Ernest Hemingway, to illustrate the treatment's dramatically negative consequences. Hemingway evidently received ECT on two separate occasions in the one to two years prior to his suicide in 1961. The issue raised by ECT opponents was the relationship between his ECT and his suicide. Although there was no popular press linkage of Hemingway's suicide to his ECT at the time of his death, later articles and biographies made a case for the connection. According to ECT opponent John Friedberg, Hemingway allegedly said that ECT-induced memory loss led directly to his suicide (Friedberg, 1975). Another anti-ECT activist, Jan Eastgate, characterized Hemingway as a "victim" of ECT (Eastgate, 1998). Two of Hemingway's biographers, A. E. Hotchner and Kenneth Lynn, emphasized that Hemingway's serious mental illness and plans for suicide significantly predated his ECT treatments (Hotchner, 1966; Lynn, 1987). Two other biographers, though, quoted extensively from anti-ECT literature and implied that the treatment was at best an atrocity committed on the great writer, at worst a direct cause of his suicide (Meyers, 1985; Reynolds, 1999). Since Hemingway was unable to speak for himself, and there was a clearly bad outcome to his life, his story was used by opponents of ECT to illustrate the profound dangers of psychiatric control over patients, especially ones as beloved as Hemingway. ECT opponents suggested that if someone as powerful as Hemingway was unable to withstand his psychiatrists' suggestions to undergo ECT, the rest of the public was in grave danger.

While opponents of ECT told the story of Hemingway and other individuals they identified as victims of the treatment (Barber, 1995; Bockris, 1995), psychiatrists began to more directly engage the public on the importance of ECT as a modern treatment by the middle of the 1980s. A number of psychiatrist groups began to meet to discuss the treatment and its uses, and an increasing number of psychiatrist advocates for ECT, particularly Harold Sackheim and Max Fink, began to make more assertive efforts to counter opponents' representations of ECT. And, as they constructed their arguments in favor of ECT, they also placed ECT in a framework of a history of progression in science and medicine. While opponents of ECT continued to link the treatment to cruelties in the past and the present, advocates extolled ECT's place among modern psychiatric treatments. Further, these advocates reiterated the older image of ECT as a positive tool against psychiatric illness, not a tool to be used against patients.

One of the ways in which advocates for ECT began to focus on its status as a modern treatment was by describing its specificity of action on the brain. To illustrate this, researchers pointed out that the "bad image" of ECT in the past had been due to psychiatrists' old practice of using too many treatments (sometimes 50 or more) in patients with a wide variety of ailments. Instead, the modern method of ECT was to use the lowest possible electrical dose for the lowest number of treatments, and to focus the treatment on specific illnesses such as depression (Bower, 1985a, 1985c; Rosenfeld, 1985). In an era in which medications for the 
diagnosis of depression were increasingly seen as specific and scientific, advocates were able to place ECT in the spectrum of treatments available to patients who were experiencing depressive symptoms (Healy, 1997; Hirshbein, 2006).

In 1985, Columbia University researcher Harold Sackheim explained and defended ECT within a lengthy article in Psychology Today. While acknowledging that "Many people believe that ECT is barbaric and repugnant," Sackheim insisted that ECT had been used successfully for more than 40 years. He admitted that there were several aspects of ECT's past that probably led to problems with ECT, particularly the once-held belief that epileptics do not suffer from schizophrenia (leading to an inappropriate use of ECT for schizophrenics). Sackheim acknowledged that, although the procedure itself had significantly improved, not all physicians were updating themselves or their equipment - he pointed out that a survey in Great Britain found that "Too many doctors used antiquated or questionable procedures" (40). Sackheim expressed confidence that new research and refined techniques would lead to a greater acceptance of ECT (Sackheim, 1985).

At the same time that Sackheim published his Psychology Today article, the National Institutes of Health assembled an advisory panel to address the issues of safety and efficacy in ECT. The panel, which included psychiatrists and psychologists, as well as a lawyer and a consumer advocate, cautiously endorsed ECT, but only for treatment for depression. As Science News coverage explained, "The panel acknowledges that during the 1940s and 1950s ECT was often overused and misused with a variety of disorders" (Bower, 1985b). A Science explanation of the panel also alluded ECT's problematic past: "Introduced in the United States in 1940, ECT has a checkered past, having been applied indiscriminately to a range of mental disorders and misused for the purpose of making patients more tractable" (Holden, 1985, p. 1510). As part of the evaluation of ECT, the Federal Drug Administration reviewed ECT machines for their use in treating mental disorders. Advocates for approval of the machines insisted that the treatment had been considerably refined since it origins with Cerletti and Bini and their observation of pigs (Weck, 1986).

By the late 1980s, ECT was increasingly mentioned as a possible therapy for depression for patients who had not responded to medication. But writers acknowledged that the image of ECT was not good: ECT, "the oldest of the treatments in use for depression-has never quite lived down its spooky reputation as a psychiatric torture callously practiced on the poor and helpless, an indelible image left behind by popular movies like One Flew Over the Cuckoo's Nest" (Cherry, 1986, p. 38). In contrast to what they asserted was the misrepresentation of Cuckoo's Nest, advocates by the late 1980s began to tell the story of ECT as a misunderstood progressive treatment. As journalist Susan Squire wrote in 1987 in the New York Times Magazine, "ECT's appearance in American psychiatric hospitals in 1940 greatly excited medical humanitarians. In comparison with the largely inadequate and often cruel physical treatments that were then available - insulin coma, sedation, psychosurgery and restraint in wet-sheet packs-ECT seemed clean, even benevolent" (Squire, 1987, p. 85). In this account, ECT became the more progressive option against a backdrop of a history of frightening and extreme psychiatric treatments - none of which was in use anymore. Although psychiatrists were still quoted as admitting that ECT was misused in the past, advocates of the treatment began to make more explicit links of ECT to research and to more modern technological devices. In Squire's article, for example, the ECT machine was reported to look like a VCR. Further, Squire framed her article with the account of a profoundly depressed woman whose depression was eliminated with ECT.

Like the Squire article, sympathetic accounts of ECT increasingly began to emphasize the effects of the treatment on people with severe depression (Lally, Meyers, \& Sangiorgio, 
1990). ECT opponents' dire warnings that ECT caused brain damage were not supported by new brain imaging techniques and new uses of ECT for ailments such as Parkinson's disease (“An Inside Look at Electroshock," 1988; "Shock Therapy's Parkinsonian Potential," 1989). Popular writers began to report that ECT had returned and that, despite its "checkered history of abuse" it had improved so much that the National Institute of Mental Health endorsed it as a valuable treatment ("Shock Therapy Returns," 1990). In addition, writers stressed that the amount of electricity used for ECT was "barely enough to cause a 10-watt light bulb to flicker" (Perlmutter, 1990, p. 52). The power of ECT, by these accounts, lay not in its electrical power but rather in its links to new brain technologies.

The language used to describe ECT by the supporters and the opponents of ECT revealed a great deal about how they understood the treatment and its relationship to history. Those who were generally disposed to favor the treatment used metaphors that reflected modern, late twentieth-century society, while those who were opposed to ECT used the language of frightening events from the past in order to describe the treatment. For example, writer Nicholas Owen published a 1998 article in Washingtonian describing the miracle of his mother's recovery after ECT. While he was nervous about the treatment (because of images provided by The Snake Pit and One Flew Over the Cuckoo's Nest), "One doctor compared ECT to rebooting a computer when the screen freezes; it fixes the problem, although you're not sure how" (Owen, 1998). This metaphor made a great deal of sense to the growing number of readers of popular magazines in the 1990s who were experiencing computer rebooting as part of everyday life. Further, recent articles about ECT have emphasized that ECT had given rise to "high tech anti-depression therapy" research, particularly in interventions such as transcranial magnetic stimulation (TMS) and vagus nerve stimulation (VNS) that worked on the same principle as ECT but without the side effects (Arner, 2003; Beame, 1999; Fischer, 2000; Hochman, 2004).

While computers and high-tech interventions appeared comfortingly modern, opponents of ECT focused on the power dynamics of ECT and used images of near-electrocution and Nazi torture to describe the treatment. Kathleen Hirsch wrote a 1995 Ms. article about the return of ECT and expressed her worry about the treatment of the past, characterized by "several weekly treatments of near-lethal amounts of electricity, for as many as 100 sessions - all without the benefit of anesthesia, and often without [the patients'] consent" (Hirsch, 1995, p. 35). Jan Eastgate, the president of the Citizens Commission on Human Rights (an activist group founded by the Church of Scientology that was opposed to psychiatric therapies, including ECT) (Kneeland \& Warren, 2002; Smith, 2001; Vatz \& Weinberg, 1994), published a 1998 USA Today article that was strident in its opposition to ECT. Eastgate explained the history of the treatment, that "electroshock 'treatment' first was used to render slaughterhouse pigs unconscious to make it easier to slit their throats. In 1938, Italian psychiatrist Ugo Cerletti decided to try this procedure on humans" (28). Eastgate went on to claim that ECT was used by Nazi psychiatrists during World War II. Eastgate even implied that the treatment was a lead-in to the mass gassing of mental patients during the war (Eastgate, 1998).

Was ECT a modern tool that could be used to eradicate illness, or an ongoing method in psychiatry's tradition of subjugating patients? By the 1990s, popular accounts of ECT began to question this dichotomized view, particularly as they included patients' perspectives. ECT recipients, while acknowledging the power issues with ECT, tended to emphasize the ways in which the treatment helped them in their battle against disease. In 1994, for example, journalist Gene Stone wrote an article for New York that centered on an ECT patient whom Stone was allowed to shadow at Hillside Hospital in Queens. Although he was prepared for drama because of the major controversy over the procedure, Stone reported that he found the 
treatment somewhat mundane. According to Stone, the ECT machine "resembles an old stereo receiver component" (57), while the ECT doctor himself was warm and supportive: "It's hard to portray him as the hard-hearted villain the anti-ECT forces believe he is" (Stone, 1994, p. 58). Other patients who experienced benefit from ECT wrote or were quoted in the 1990s emphasizing both how beneficial they found the treatment, and how undramatic it really was ("Electroconvulsive Therapy Works Well," 1995; Hubbard \& Kramer, 1995).

Over the last decade, more individuals who directly experienced ECT have made the public point that the treatment helped them in ways that medications and psychotherapy could not. Martha Manning, a psychologist, wrote a memoir about her treatment for depression and her attempt to be treated with psychotherapy. Much to her dismay, therapy did not seem to work: "II saw therapy alone couldn't fix it. It was like practicing a religion and finding out when you die that it wasn't the right one"' (Hubbard \& Kramer, 1995). Manning went on to recover with the help of ECT. Andy Behrman, a New Yorker who was diagnosed with manicdepressive disorder, wrote first person accounts of his experiences with ECT (first an article, then a book) in which he embraced the treatment and how it made him feel. Although he reported some memory problems, he also used language of religious experience in order to describe his appreciation of what the treatment had done for him (Behrman, 1999, 2002).

Kitty Dukakis, the most recent celebrity to discuss her experience with ECT, did not let anyone else define her experience with the treatment. In a well-publicized book (Dukakis, 2006), Dukakis and her co-author, former Boston Globe health journalist Larry Tye, interspersed Dukakis's accounts of her mental illness and ECT with Tye's perspective on the history and controversy over the treatment (Dukakis \& Tye, 2006). Although Tye discussed the unpleasant and unfortunate aspects of ECT's history, he placed the treatment in the context of other drastic medical interventions: "Like chemotherapy, ECT is a toxic treatment for a crippling disease. Like any surgery requiring anesthesia, it carries risks. And like the electric paddles that cardiologists use to shock a fibrillating heart back into rhythm, ECT is not a cure but can offer relief and even remission" (xi). In Dukakis's part of the story, she embraced the idea of shock as a treatment and even named her book Shock. Dukakis acknowledged that the treatment was controversial, but pleaded for discussion about it:

So let me be clear. I am saying that ECT worked for me, not that it will work for everybody. I am saying that we need to face up to ECT's risks and try to reduce them, but we also need to acknowledge its potential benefits. I am saying, more than anything, that talking about this is a good thing. There are too many people in desperate need of a workable treatment to limit any viable options. There is too much need for open discussion to continue the vitriol and finger pointed that have characterized the last half century of debate about ECT (194).

Dukakis, like other recent patients, insisted that informed patients were able to make clear choices for themselves. ECT was not a torture imposed on her or others against their will, nor was it entirely free of risks. Instead, it was a powerful tool with possible side effects that dramatically helped some people.

\section{CONCLUSION}

In 1999, State University of New York at Stony Brook psychiatrist Max Fink published a book intended to educate the public about ECT. After explaining the procedure and the typical patient's experience, Fink went on to describe the origins of ECT. He reported that electroconvulsive therapy came from chemical convulsive therapy developed by Hungarian physician Ladislas Meduna. Like other writers who described the origins of ECT, Fink 
explained that abuses were common in its early history. In Fink's account, the abuses largely stemmed from a lack of science: "chance, adventurism, bravado, and disregard for scientific investigation set off a rash of treatments that were most often applied without formal testing for efficacy or for safety" (90). Fink also explained that ECT was often done without regard to patient consent in its early years - but that consent procedures set up specifically to address the issue of ECT helped to shape the concept of informed consent for psychiatric treatment in the 1970s. According to Fink, the problems from the past had all been solved with regard to ECT (Fink, 1999).

Fink's account, like other advocate explanations of ECT, emphasized that problematic power relationships between psychiatrists and patients were only in the past. According to Fink, historical psychiatric abuses with ECT stemmed from overly zealous psychiatrists who wanted too much to help their patients - these abuses were eventually corrected by improved scientific understanding and technique. But opponents of ECT have argued in contrast that the dynamics of the treatment continue to depend on an absolute power relationship in which psychiatrists inflict dangerous procedures on duped or powerless patients. By invoking the language of concentration camp torture, ECT opponents have made the strongest possible connection between totalitarian practices and psychiatric interactions with patients.

Within the conflict generated by advocate and opponent opinions of ECT, new voices have appeared in the last few decades. Consumers of ECT have had an increasingly vocal presence within this debate about the power and the history of ECT. Some ECT patients have declared themselves victims of this procedure and have worked hard to ban the practice. Others, however, have gone public and insisted that they chose ECT with open minds in order to help treat their severe illnesses. In the case of ECT, as with many other areas of medicine in the twentieth century (Tomes, 2001), consumers' entrance into the discourse around their treatment has amplified and complicated the discussion about ECT's present, past, and ongoing power dynamics. Part of the job of advocates and opponents has become to persuade potential consumers of their version of the history of ECT.

From a strategic point of view, it is obvious why the opponents of ECT want to maintain that the treatment was characterized by abuses early (as well as later) in its history. The worst thing that could happen is that contemporary testimonies of celebrities such as Kitty Dukakis could undermine their argument that ECT is still barbaric and essentially a way to torture patients. But ECT supporters who use a progressive historical narrative and blame the past in order to highlight ECT's present scientific status are taking a bit of a gamble. First, the argument that ECT is much better than it used to be does not explain the uncomfortable fact that ECT practitioners still do not have a clear idea of why ECT works. Second, patient advocates of ECT temper their enthusiasm for the treatment with warnings about serious side effects that still affect patients, even with improved modern procedures. Finally, the positioning of older styles of ECT as characteristic of the bad old days - eliminated through the use of new interventions - puts leaders in American psychiatry in a bind as they have to comment on the ECT practices in other countries, some of which do not have enough resources to implement ECT improvements such as anesthesia. ${ }^{7}$

No matter who defines the history of ECT, the treatment does involve a very real power dynamic between practitioner and patient. In no other psychiatric treatment is a patient as passive - or as unaware of the treatment itself while it is occurring. Patients who undergo the treatment have to accept that their surrender of power is worth it in the end. And psychiatrists

7. Personal communication, Dr. Daniel Maixner, Director, ECT Program, University of Michigan Hospitals, 8 January 2007. 
who perform the treatment have to understand and respect the power that they wield. While ECT is seldom performed on involuntary patients and ECT opponents are wildly distorting the past by connecting the treatment to Nazi atrocities, critics have identified a power dynamic that has existed to some extent through much of psychiatry's history. Psychiatrists cannot simply claim that all of that is in the past.

\section{REFERENCES}

Abir-Am, P. G. (1999). The first American and French commemorations in molecular biology: From collective memory to comparative history. Osiris, $14,324-372$.

Altheide, D. L. (1977). Mental illness and the news: The Eagleton story. Sociology and Social Research, 61, $138-155$.

Appel, K. E., Farr, C. B., \& Marshall, H. K. (1928). Insulin therapy in undernourished psychotic patients: Preliminary report. Journal of the American Medical Association, 90, 1788-1789.

Arner, F. (2003, 8 September). Shock therapy leaves the cuckoo's nest. Business Week, 98, 100.

Avery, D. (1977, August). Case for shock therapy. Psychology Today, 11, 104.

Barber, S. (1995, February). Cruel journey. Art in America, 83, 70-75.

Bayer, R. (1987). Homosexuality and American psychiatry: The politics of diagnosis (Revised ed.). Princeton, NJ: Princeton University Press.

Beame, R. (1999, 20-27 December). Batteries not included. New York, 32, 22.

Behrman, A. (1999, 17 January). Electroboy. New York Times Magazine, A1.

Behrman, A. (2002). Electroboy: A memoir of mania. New York: Random House.

Bennett, A. E. (1939). Metrazol convulsive shock therapy in affective psychoses. American Journal of the Medical Sciences, 198, 695-701.

Berrios, G. E. (1997). The scientific origins of electroconvulsive therapy: a conceptual history. History of Psychiatry, $8,105-119$.

Bianchi, J. A., \& Chiarello, C. J. (1944). Shock therapy in the involutional and manic-depressive psychoses. Psychiatric Quarterly, 18, 118-126.

Bliss, M. (1984). The discovery of insulin. Chicago: University of Chicago Press.

Bockris, V. (1995, August). Lou Reed: The life of a rocker who knows all the hard places. Interview, 25, 20-22.

Bodnar, J. (1992). Remaking America: Public memory, commemoration, and patriotism in the twentieth century. Princeton, NJ: Princeton University Press.

Bormann, E. G. (1973). The Eagleton affair: A fantasy theme analysis. Quarterly Journal of Speech, 59, $143-159$.

Bower, B. (1985a, 26 January 1). ECT: All seizures are not the same. Science News, 127, 53.

Bower, B. (1985b, 22 June). Panel okays ECT, calls for U.S. survey. Science News, 127, 389.

Bower, B. (1985c, 2 February). The patients' perspective on ECT: Of mice and men .... and depression. Science News, $127,74$.

Braslow, J. (1997). Mental ills and bodily cures: Psychiatric treatment in the first half of the twentieth century. Berkeley: University of California Press.

Bukstein, E. (1963, February). Electric shock on purpose. Electronics World, 69, 29-32, 97-28.

Cherry, L. (1986, 2 June). The good news about depression. New York, 19, 32-42.

Chinnici, M. (1984, October). Electroshock therapy on trial. Science Digest, 92, 14.

Clark, M., \& Lubenow, G. C. (1975, 17 March). Attack on electroshock. Newsweek, 85, 86.

Clark, M., Schmidt, M., \& Hager, M. (1982, 25 October). Voting on electroshock. Newsweek, 100, 105.

Comeback for shock therapy? (1979, 19 November). Time, 114, 76.

Dain, N. (1989). Critics and dissenters: Reflections on 'anti-psychiatry' in the United States. Journal of the History of the Behavioral Sciences, 25, 3-25.

Depression and electroshock. (1972, 7 August). Newsweek, 80, 20.

Depression: Safer shock therapy. (1980, 25 October). Science News, 118, 266.

Dukakis, K. (2006, 18 September). I feel good, I feel alive. Newsweek, 148, 62-63.

Dukakis, K., \& Tye, L. (2006). Shock: The healing power of electroconvulsive therapy. New York: Avery.

Eastgate, J. (1998, November). The case against electroshock treatment. USA Today, 127, 28-30.

ECT: It works, but at what cost? (1978, 25 November). Science News, 114, 359.

Electric shock stops heart twitching. (1957, 2 February). Science News Letter, 71, 73.

Electric shock treatment causes partial memory loss. (1941, 20 September). Science News Letter, 40, 182-183.

Electric shock used to halt heart twitching. (1957, May). Radio and Television News, 57, 101.

Electroconvulsive therapy works well. (1995, February 1). USA Today, 123, 12-13.

Ellis, J. W. (1975, Spring). Law. MH, 59, 5.

English, O. S., \& Finch, S. M. (1964). Introduction to psychiatry (3rd ed.). New York: W.W. Norton \& Company.

Essig, M. (2003). Edison and the electric chair: A story of light and death. New York: Walker.

Evaluating Eagleton. (1972, 14 August). Time, 100, 41.

Feldt, R. H. (1945, February). The shock that cures. Science Digest, 17, 21-25. 
Fink, M. (1991). Impact of the antipsychiatry movement on the revival of electroconvulsive therapy in the United States. Psychiatric Clinics of North America, 14, 793-801.

Fink, M. (1999). Electroshock: Healing mental illness. New York: Oxford University Press.

Fischer, J. S. (2000, 24 January). Taking the shock out of electroshock. U.S. News \& World Report, 128, 46.

Fishbein, L. (1979). The Snake Pit (1948): The sexist nature of sanity. American Quarterly, 31, 641-665.

Foucault, M. (1967). Madness and civilization: A history of insanity in the age of reason (R. Howard, Trans.). New York: Pantheon.

Freeman, L. (1953, September). We're overdoing shock treatments. Science Digest, 34, 26-29.

Friedberg, J. (1975, August). Electroshock therapy: Let's stop blasting the brain. Psychology Today, 9, 18-25.

Gabbard, G. O., \& Gabbard, K. (1999). Psychiatry and the cinema (2nd ed.). Washington, D.C.: American Psychiatric Press.

Galton, L. (1958, March). Relief for intolerable pain. Cosmopolitan, 144, 8.

Grob, G. N. (1983). Mental illness and American society, 1875-1940. Princeton, NJ: Princeton University Press.

Hale, N. G., Jr. (1995). The rise and crisis of psychoanalysis in the United States: Freud and the Americans, 1917-1985. New York: Oxford University Press.

Hapgood, F. (1980, January). Electroshock: The unkindest therapy of all. Atlantic Monthly, 245, 53-59.

Healy, D. (1997). The antidepressant era. Cambridge, MA: Harvard University Press.

Healy, D. (2002). The creation of psychopharmacology. Cambridge, MA: Harvard University Press.

Herbert, W. (1982, 13 November). Berkeley voters ban ECT, shock psychiatric profession. Science News, 122, 309.

Herbert, W. (1983, 29 January). ECT ban banned. Science News, 123, 71.

Hirsch, K. (1995, November/December). Shock therapy makes a comeback. Ms., 6, 3436.

Hirshbein, L. D. (2006). Science, gender, and the emergence of depression in American psychiatry, 1952-1980. Journal of the History of Medicine \& Allied Sciences, 61, 187-216.

Hochman, A. (2004, January/February). The return of shock therapy. Health, 96-100.

Hoenig, J. (1995). Schizophrenia: Clinical section. In G. E. Berrios \& R. Porter (Eds.), A history of clinical psychiatry: The origins and history of psychiatric disorders (pp. 336-348). London: The Athlone Press.

Holden, C. (1985, 28 June). A guarded endorsement for shock therapy. Science, 228, 1510-1511.

Hotchner, A. E. (1966). Papa Hemingway: A personal memoir. New York: Random House.

Hubbard, K., \& Kramer, L. (1995, 19 June). Dark victory. People, 43, 65-66.

An inside look at electroshock. (1988, 11 June 1988). Science News, 133, 382.

Insulin sub-shock treatment for mental illness. (1949, 23 May). Newsweek, 33, 50-51.

Jackson, S. W. (1986). Melancholia and depression: From Hippocratic times to modern times. New Haven, CT: Yale University Press.

Kalinowsky, L. B., \& Worthing, H. J. (1943). Results with electric convulsive therapy in 200 cases of schizophrenia. Psychiatric Quarterly, 17, 144-153.

Kammen, M. (1991). Mystic cords of memory: The transformation of tradition in American culture. New York: Vintage Books.

Kennedy, A. (1940). The treatment of mental disorders by induced convulsions. Journal of Neurology and Psychiatry, 3, 49-82.

Kesey, K. (1962). One flew over the cuckoo's nest. New York: New American Library.

Kneeland, T. W., \& Warren, C. A. B. (2002). Pushbutton psychiatry: A history of electroshock in America. Westport, CT: Praeger.

Kraepelin, E. (1907). Clinical psychiatry. New York: Macmillan.

Lally, S., Meyers, M., \& Sangiorgio, M. (1990, January). Dictionary of healing techniques and remedies: Electroconvulsive therapy. Prevention, 1990, 135-136.

Laqueur, H. P. (1959, 28 December). Now: New treatment for mental illness. U.S. News \& World Report, 47, 60-64.

Lauer, M. (Writer) (2005). "I'm passionate about life;" Actor Tom Cruise talks with Today host Matt Lauer about his new love, new movie and his recent controversial comments, Today Show.

Lebensoh, Z. M. (1999). The history of electroconvulsive therapy in the United States and its place in American psychiatry: A personal memoir. Comprehensive Psychiatry, 40, 173-181.

Lederer, S. E. (1995). Subjected to science: Human experimentation in America before the second World War. Baltimore: Johns Hopkins University Press.

Levy, N., \& Grinker, R. R. (1943). Psychological observations in affective psychoses treated with combined convulsive shock and psychotherapy. Journal of Nervous and Mental Disease, 97, 623-637.

Lunbeck, E. (1994). The psychiatric persuasion: Knowledge, gender, and power in modern America. Princeton, NJ: Princeton University Press.

Lynn, K. S. (1987). Hemingway. New York: Simon and Schuster.

Malzberg, B. (1943). The outcome of electric shock therapy in the New York civil state hospitals. Psychiatric Quarterly, 17, 154-163.

Many mentally ill now getting shock treatment. (1942, 30 May). Science News Letter, 41, 345.

Many spinal fractures in shock treatments. (1940, 17 August). Science News Letter, 38, 105.

Martschukat, J. (2002). The art of killing by electricity: The sublime and the electric chair. Journal of American History, 89, 900-921. 
McCrae, N. (2006). A violent thunderstorm: Cardiazol treatment in British mental hospitals. History of Psychiatry, 17, 67-90.

McDonald, A., \& Walter, G. (2001). The portrayal of ECT in American movies. Journal of ECT, 17, 264-274.

McGovern begins. (1972, 14 July). New York Times, p. 30.

McGovern calls Eagleton affair "saddest part.” (1972, 13 December). New York Times, p. 47.

Meeting on minds. (1949, 6 June). Newsweek, 33, 47-49.

Menninger, W. C. (1940). An evaluation of metrazol treatment. Bulletin of the Menninger Clinic, 4, 95-104.

Mental disease preventive. (1945, 5 May). Science News Letter, 47, 277.

Messinger, E. (1941, August). Pharmacologic shock treatment for mental disease. Scientific Monthly, 53, 155-164.

Meyers, J. (1985). Hemingway: A biography. New York: Harper \& Row.

Micale, M. S., \& Porter, R. (Eds.). (1994). Discovering the history of psychiatry. New York: Oxford University Press.

Moran, R. (2002). Executioner's current: Thomas Edison, George Westinghouse, and the invention of the electric chair. New York: Knopf.

More or less shock? (1955, 21 May). Science News Letter, 67, 325.

Most common mental disorder. (1972, 7 August). Time, 100, 16-17.

New shock treatment. (1958, 21 June). Science News Letter, 73, 388.

Novick, P. (1999). The holocaust in American life. Boston: Houghton Mifflin Company.

Nussbaum, K. (1943). Observations on electric shock treatment. Psychiatric Quarterly, 17, 327-336.

Ogbar, J. O. G. (2004). Black power: Radical politics and African American identity. Baltimore: Johns Hopkins University Press.

Ostlund, L. E. (1973/74). Interpersonal communication following McGovern's Eagleton decision. Public Opinion Quarterly, 37, 601-610.

Owen, N. (1998, August). Back to life. Washingtonian, 33, 45-50.

Passione, R. (2004). Italian psychiatry in an international context: Ugo Cerletti and the case of electroshock. History of Psychiatry, 15, 83-104.

Perlmutter, C. (1990, October). Beyond thought therapy. Prevention, 42, 50-52.

Photoshock treats psychosis. (1952, 24 May). Science News Letter, 61, 332.

Pressman, J. D. (1998). Last resort: Psychosurgery and the limits of medicine. New York: Cambridge University Press.

Read, C. F. (1940, July). Shock treatment for mental disorders. Hygeia, 18, 627-628.

Reader's Guide to Periodical Literature (1901-). 2006

Rennie, T. A. C., \& Fowler, J. B. (1943). Prognosis in manic-depressive and schizophrenic conditions following shock treatment. Psychiatric Quarterly, 17, 642-654.

Reynolds, M. (1999). Hemingway: The final years. New York: W.W. Norton \& Company.

Rinkel, M., \& Himwich, H. E. (Eds.). (1959). Insulin treatment in psychiatry. New York: Philosophical Library.

Rogers, J. (1982, 31 May). A stir over electroshock. Maclean's, 95, 52.

Rosen, S. R., Secunda, L., \& Finley, K. H. (1943). The conservative approach to the use of shock therapy in mental illness. Psychiatric Quarterly, 17, 617-641.

Rosenfeld, A. H. (1985, June). Depression: Dispelling despair. Psychology Today, 19, 28-34.

Rothman, D. J. (1990). The discovery of the asylum: Social order and disorder in the New Republic (Rev. ed.). Boston: Little, Brown and Company.

Roueche, B. (1974, 9 September). As empty as Eve. New Yorker, 50, 84+.

Sackheim, H. A. (1985, June). The ease for ECT. Psychology Today, 19, 36-40.

Sadowsky, J. H. (2006). Beyond the metaphor of the pendulum: Electroconvulsive therapy, psychoanalysis, and the styles of American psychiatry. Journal of the History of Medicine \& Allied Sciences, 61, 1-25.

Scarf, M. (1979, 17 June). Shocking the depressed back to life. New York Times Magazine, 32-42.

Schreiber, F. R., \& Herman, M. (1965, September). Now, shock therapy by chemistry. Science Digest, 58, $28-31$.

Schulman, B. J. (2001). The seventies: The great shift in American culture, society, and politics. Cambridge, MA: Da Capo Press.

Scull, A. (2005). Madhouse: A tragic tale of megalomania and modern medicine. New Haven, CT: Yale University Press.

Servaas, C. (1981, May/June). Kidney stone shock waves. Saturday Evening Post, 253, 122-123.

Shock for stammerers. (1948, 5 April). Newsweek, 32, 51.

Shock therapy returns. (1990, 26 March). Newsweek, 115, 44.

Shock therapy's Parkinsonian potential. (1989, 9 December). Science News, 136, 381.

The shocked heart. (1952, 11 February). Newsweek, 39, 85.

Shocked to life. (1952, 11 February). Time, 59, 42.

Shocking alternative to open heart surgery. (1981, 2 May). Science News, 119, 279.

Shorter, E. (1997). A history of psychiatry: From the era of the asylum to the age of Prozac. New York: John Wiley \& Sons.

Silber, N. (1993). The romance of reunion: Northerners and the South, 1865-1900. Chapel Hill, NC: University of North Carolina Press.

Smith, D. (2001, February). Shock and disbelief. Atlantic Monthly, 287, 79-90.

Squire, S. (1987, 22 November). Shock therapy's return to respectability. New York Times Magazine, 78-79, 85, $88-79$. 
Stone, G. (1994, 14 November). Short sharp shocks. New York, 27, 54-59.

Strout, L. N. (1995). Politics and mental illness: The campaigns of Thomas Eagleton and Lawton Chiles. Journal of American Culture, 18, 67-73.

Sulzbach, W., Tillotson, K. J., Guillemin, V., Jr., \& Sutherland, G. F. (1943). A consideration of some experiences with electric shock treatment in mental diseases, with special regard to various psychosomatic phenomena and to certain electrotechnical factors. American Journal of Psychiatry, 99, 519-524.

Talkington, P. C. (1972, 7 August). Electroshock therapy: Its uses - and effects. U.S. News \& World Report, $73,17$.

Tomes, N. (1994). Feminist histories of psychiatry. In M. S. Micale \& R. Porter (Eds.), Discovering the history of psychiatry (pp. 348-383). New York: Oxford University Press.

Tomes, N. (2001). Merchants of health: Medicine and consumer culture in the United States, 1900-1940. Journal of American History, 88, 519-547.

Turner, T. (1995). Schizophrenia: Social section. In G. E. Berrios \& R. Porter (Eds.), A History of clinical psychiatry: The origin and history of psychiatric disorders (pp. 349-359). London: The Athlone Press.

Valenstein, E. S. (1986). Great and desperate cures: The rise and decline of psychosurgery and other radical treatments for mental illness. New York: Basic Books.

Van de Water, M. (1940, 20 July). Electric shock, a new treatment to restore patients with hopeless mental disease. Science News Letter, 38, 42-44.

Vatz, R. E., \& Weinberg, L. S. (1994). The rhetorical paradigm in psychiatric history: Thomas Szasz and the myth of mental illness. In M. S. Micale \& R. Porter (Eds.), Discovering the history of psychiatry (pp. 311-330). New York: Oxford University Press.

Weck, E. (1986, March). Electro'shock' therapy: Controversy without end? FDA Consumer, 20, 8-11.

Weiner, R. D., \& Coffey, C. E. (1991). Electroconvulsive therapy in the United States. Psychopharmacology Bulletin, $27,9-15$.

Wilson, D. C. (1939). The results of shock therapy in the treatment of affective disorders. American Journal of Psychiatry, 96, 673-679.

Ziskind, E., Somerfeld-Ziskind, E., \& Ziskind, L. (1942). Metrazol therapy in the affective psychoses. Journal of Nervous and Mental Disease, 95, 460-473.

Ziskind, L. (1948, December). Caseworker's relation to shock therapy. Survey Midmonthly, 84, 370. 